\title{
Association of Nerve Growth Factor Receptors with the Triton X-100 Cytoskeleton of PC12 Cells ${ }^{1}$
}

\author{
RONALD D. VALE, MICHAEL J. IGNATIUS, AND ERIC M. SHOOTER ${ }^{2}$ \\ Department of Neurobiology, Stanford University School of Medicine, Stanford, California 94305
}

\begin{abstract}
Triton X-100 solubilizes membranes of $\mathrm{PC} 12$ cells and leaves behind a nucleus and an array of cytoskeletal filaments. Nerve growth factor (NGF) receptors $(10 \%$ of those found in intact cells) are associated with this Triton $\mathrm{X}-100$ insoluble residue. Two classes of NGF receptors are found on PC12 cells which display rapid and slow dissociating kinetics. Although rapidly dissociating binding is predominant $(>75 \%)$ in intact cells, the majority of binding to the Triton $X-100$ cytoskeleton is slowly dissociating $(>75 \%)$. Rapidly dissociating NGF binding on intact cells can be converted to a slowly dissociating form by the plant lectin wheat germ agglutinin (WGA). This lectin also increases the number of receptors which associate with the Triton X-100 cytoskeleton by more than 10 -fold. ${ }^{25}$ I-NGF bound to receptors can be visualized by light microscopy autoradiography in Triton X-100-insoluble residues of cell bodies, as well as growth cones and neurites. The WGA-induced association with the cytoskeleton, however, is not specific for the NGF receptor, since $>90 \%$ of cell surface glycoprotein receptors for WGA become associated with Triton X-100-insoluble material at lectin concentrations greater than $33 \mu \mathrm{g} / \mathrm{ml}$. Concentrations of WGA which change the Triton $X-100$ solubility of membrane glycoproteins are similar to those required to alter the kinetic state of the NGF receptor. Both events may be related to the crossbridging of cell surface proteins induced by this multivalent lectin.
\end{abstract}

Plasma membrane proteins were once thought to diffuse freely in the plane of the lipid bilayer. However, a good deal of evidence has accumulated in recent years indicating that many membrane proteins associate with a subcortical cytoskeletal network (Branton et al., 1981; Mescher et al., 1981; Pober et al., 1981). This transmembrane interaction has many irriporlant consequences for cellular function. Connections between the cytoskeleton and the membrane are important for controlling cell shape and locomotion (Hellewell and Taylor, 1979; Stossel, 1982) and may regulate many other dynamic membrane processes such as patching, capping, and internalization of cell surface antigens (Bourguignon and Singer, 1977; Condeelis, 1979). Furthermore, cytoskeletal regulation of

Received November 30, 1984; Revised April 10, 1985;

Accepted April 10, 1985

\footnotetext{
${ }^{1}$ This work was supported by National Institutes of Health Grant NS 04270 , American Cancer Society Grant BC 325, and the Isabella Niemala Trust. R. $D$. $V$. is a sludert in the Medical Scientist Training Program and is supported by National Institutes of Health Grant GM 07365 . M. J. I. was supported by National Institute of Mental Health Training MH 17047

${ }^{2}$ To whom correspondence should be addressed.
}

membrane protein mobility (Schlessinger et al., 1976; Koppel et al., 1981; Carraway et al., 1983) allows for the formation of specialized membrane domains, as demonstrated by the clustering of acelylcholine receptors at synaptic junctions (Prives et al., 1982). In the erythrocyte, proteins responsible for linking membrane proteins to actin microfilaments have been identified and purified (Bennett, 1982); however, in non-erythroid cells, the biochemistry of membrane-cytoskeletal interactions is still poorly understood. In the last few years, though, proteins similar in nature to erythroid spectrin and ankyrin have been identified in other cell types (Burridge et al., $1982 \mathrm{~b}$ ), and novel proteins which may play a role in transmembrane linkage have also been found (Burridge et al., 1982a; Carraway et al., 1983).

Nerve growth factor (NGF), a hormone which plays an essential role in neuronal development (Thoenen and Barde, 1980; Yankner and Shooter, 1982), interacts with specific cell surface receptors on a cultured pheochromocytoma cell line, PC12 (Herrup and Thoenen, 1979; Landreth and Shooter, 1980). Receptor binding initiates a sequence of events which transforms PC12 cells into a cell phenotype resembling a sympathetic neuron (Greene and Tischler, 1976). Two types of NGF receptors with high and low affinity have been identified on responsive cells (Sutter et al., 1979a; Landreth and Shooter, 1980). The two receptors can be easily distinguished by their dissociation kinetics, as ${ }^{125}$ I-NGF is released 10 to 100 times more slowly from high affinity than from low affinity receptors. Previously, Schechter and Bothwell (1981) found that ${ }^{125}$ |-NGF, bound to slowly dissociating receptors, was resistant to Triton $X$ 100 solubilization whereas rapidly dissociating binding was completely solubilized. They proposed that an association of slowly dissociating receptors with the cytoskeleton was responsible for their Triton X-100 insolubility.

Vale and Shooter $(1982,1983)$ later showed that rapidly dissociating NGF-receptor complexes could be converted to a slowly dissociating form by the lectin wheat germ agglutinin (WGA) (Vale and Shooter, 1982) or by anti-NGF antibodies (Vale and Shooter, 1983). The change in the kinetic state of the receptor was accompanied by a conversion of the NGF-receptor complex to a Triton $X$ 100 -insoluble form. These results suggest that an association of the NGF receptor with the cytoskeleton is correlated with a particular binding state. Recent studies by Jesaitis et al. (1984) have also shown that the conversion of the $\mathrm{N}$-formyl chemotactic peptide receptor to a slowly dissociating form on granulocytes occurs concomitantly with a transient association with the cytoskeleton. In the current study, we demonstrate that the Triton X-100-insoluble residue of PC12 cells contains NGF receptors capable of binding NGF. The slowly dissociating kinetic form of the receptor is primarily found in association with the Triton X-100 cytoskeleton, and the extent of ${ }^{125}$-NGF binding to the cytoskeletons can be greatly enhanced by prior treatment of the cells with WGA. 


\section{Materials and Methods}

\section{Materials}

WGA and concanavalin A (Con A) were purchased from Vector Laboratories. Triton X-100, lactoperoxidase, and DNase I (DN CL) were obtained from Sigma Chemical $\mathrm{Co}$. Glucose oxidase was purchased from CalbiochemBehring. NGF (the $\beta$ subunit of the $7 \mathrm{~S} \mathrm{NGF} \mathrm{complex)} \mathrm{was} \mathrm{purified} \mathrm{as}$ previously described (Mobley et al., 1976).

\section{Methods}

Indinations. NGF was radiolabeled with ${ }^{125}$ by a lactoperoxidase procedure to a specific activity of 50 to $90 \mathrm{cpm} / \mathrm{pg}$ as described by Sutter et al. (1979a). ${ }^{125}$-NGF was used within 3 weeks of its iodination. ${ }^{125}$-WGA (25 to $30 \mathrm{cpm} / \mathrm{pg}$ ) was prepared by the Sutter et al. (1979a) protocol except that $250 \mu \mathrm{g}$, instead of $50 \mu \mathrm{g}$, of protein was used in the reaction mixture. lodination of PC12 cell surface proteins was performed according to the protocol of Hynes (1973) using a lactoperoxidase/glucose oxidase coupled reaction. Labeled cells were separated from free ${ }^{125}$ by four successive $10-$ sec centrifugations at $10,000 \times \mathrm{g}$ in a microfuge with washes of Dulbecco's phosphate-buttered salıne (PBS) containing $10 \mathrm{~mm} \mathrm{KI}$ and $1 \mathrm{~mm}$ phenylmethylsulfonyl fluoride (PMSF).

Cell culture and harvesting. PC12 cells were grown in 100-mm tissue culture dishes in Dulbecco's modified Eagle's medium (DMEM) containing $10 \%$ fetal calf serum and $5 \%$ horse serum (DMEM $+S$ ) in an atmosphere of $88 \%$ air and $12 \% \mathrm{CO}_{2}$. For binding assays, dishes were washed twice with $10 \mathrm{ml}$ of PBS containing $1 \mathrm{mg} / \mathrm{ml}$ each of glucose and bovine serum albuminin (BSA) (PBS/BSA/glucose) and were harvested by trituration in 10 $\mathrm{ml}$ of the same buffer. The concentration of cells was estimated using a hemocytometer and was adjusted to between 1 and $2 \times 10^{6}$ cells $/ \mathrm{ml}$. Experimentation began immediately after removal of cells from dishes.

Preparation of Triton $X-100$ cytoskeletons. $\mathrm{PC} 12$ cells $\left(2 \times 10^{6} / \mathrm{ml}\right.$ unless indicated) were centrifuged $(500 \times g ; 5 \mathrm{~min})$ and resuspended with a 5 - or $10-\mathrm{ml}$ plastic pipette in one-half of their original volume in $0.5 \%$ Triton X-100 in $20 \mathrm{~mm}$ Tris. $\mathrm{HCl}, \mathrm{pH} 7.4,4 \mathrm{~mm} \mathrm{MgCl}_{2}, 300 \mathrm{~mm}$ sucrose, and $1 \mathrm{~mm}$ PMSF (Triton X-100 extraction buffer) for $5 \mathrm{~min}$ at $4^{\circ} \mathrm{C}$. This is the same buffer used by Ben Ze'ev et al. (1979) for extracting fibroblasts. Since cytoskeletal proteins are prominent components that remain after detergent extraction, we use the term "Triton X-100 cytoskeleton" in reference to cellular material that remains insoluble after adding detergent and pellets at low centrifugal speeds. Triton X-100 cytoskeletons were washed twice in PBS/BSA by centrifugations at $1000 \times g$ for $5 \mathrm{~min}$ at $4^{\circ} \mathrm{C}$ to remove the majority of the Triton $X-100$ detergent. The cytoskeleton pellet was then resuspended in its original volume with PBS/BSA for a final concentration of $2 \times 10^{6}$ Triton X100 cytoskeletons $/ \mathrm{ml}$. In the case of Triton X-100 cytoskeletons obtained from WGA-treated cells, WGA $(50 \mu \mathrm{g} / \mathrm{ml})$ was included in the buffer used to resuspend the cytoskeleton pellet.

Enucleation of PC12 cells. PC12 cells were subcultured for 1 to 2 days in $25-\mathrm{cm}^{2}$ flasks on extracellular matrix obtained from confluent bovine corneal endothelial cells. Enucleation was performed by first incubating cells with $8 \mu \mathrm{g} / \mathrm{ml}$ of cytochalasin in DMEM plus $10 \%$ calf serum with sufficient medium to fill the flask. The flasks were placed in a JA-10 rotor containing a $200-\mathrm{ml}$ water cushion $\left(37^{\circ} \mathrm{C}\right)$ and were centrifuged at 7,000 to $11,000 \times g$ for $15 \mathrm{~min}$ in a Beckman model $\mathrm{J}-21 \mathrm{C}$ centrifuge. The medium containing sheared nucleoplasts was aspirated, and cytoplasts were incubated with 5 $\mathrm{ml}$ of $\mathrm{Ca}^{2+}, \mathrm{Mg}^{2+}$-free PBS for $20 \mathrm{~min}$ at $37^{\circ} \mathrm{C}$. Cytoplasts were removed by trituration and were centrifuged $(500 \times g ; 5 \mathrm{~min})$ and resuspended in binding buffer. This procedure results in $>85 \%$ enucleation. In parallel with the preparation of cytoplasts, a control preparation of intact cells underwent the same treatment with the exception of cytochalasin B treatment.

${ }^{125}$ /-NGF binding. ${ }^{125}$ /NGF was added in PBS/BSA/glucose or PBS/BSA to cells and Triton X-100 cytoskeletons, respectively. All experiments were conducled in polyethylene tubes. After a given incubation, triplicate aliquots $(100 \mu$ ) were layered over $200 \mu$ of $0.15 \mathrm{M}$ sucrose in binding buffer in 400 $\mu$ microfuge tubes and centrifuged for $30 \mathrm{sec}$ at $10,000 \times g$ in a Microfuge. Bound and free ${ }^{125}$-NGF were separated by freezing the Microfuge tube in a dry ice/ethanol bath and cutting it just above the cell pellet. Nonspecific ${ }^{125}$ NGF binding was determined by incubating cells or cytoskeletons with ${ }^{125}$ NGF and $10 \mu \mathrm{g} / \mathrm{ml}$ of unlabeled NGF. Nonspecific binding was subtracted from the total bound radioactivity, and specific binding is reported for all experiments. Nonspecific binding to whole cells was generally less than $10 \%$ of the total. Triton X-100 cytoskeletons from WGA-treated and untreated cells displayed nonspecific bindings of $15 \%$ and $50 \%$, respectively. Slowly dissociating binding was determined by removing $0.4 \mathrm{ml}$ of the suspension of cells or cytoskeletons containing ${ }^{125}$ I-NGF to a tube containing $10 \mu \mathrm{l}$ of a $0.5-\mathrm{mg} / \mathrm{ml}$ solution of unlabeled NGF (final concentration of $8 \mu \mathrm{g} / \mathrm{ml}$ of unlabeled ligand) and incubating the sample on ice for $30 \mathrm{~min}$. The amount of ${ }^{125}$-NGF that remains associated with the cells or cytoskeletons after dissociation was determined by the same centrifugation assay already described and was corrected for nonspecific binding. For intact cells, Triton $X-100$-insoluble binding was determined by centrifuging triplicate $100-\mu \mathrm{l}$ aliquots through $200 \mu \mathrm{l}$ of the previously described Triton X-100 extraction buffer for $30 \mathrm{sec}$ at $10,000 \times g$ in a Microfuge. Radioactivity which pelleted was considered Triton X-100 insoluble and had Triton X-100-insoluble nonspecific binding subtracted

Light microscopic autoradiography. Cells were grown for 8 days in 50 $\mathrm{ng} / \mathrm{ml}$ of NGF in DMEM + S on poly-L-lysine $(1 \mathrm{mg} / \mathrm{ml}$, type IV, Sigma)coated polystyrene coverslips (Lux) in multiwell culture dishes (Lux). Cells were plated at a density of $2.5 \times 10^{3}$ cells $/ \mathrm{cm}^{2}$ to minimize crowding of processes and cell bodies. On day 9 cells were washed three times for $1 \mathrm{hr}$ with NGF-free DMEM + S to remove surface bound NGF. ${ }^{125}$-NGF (1 nM) in $\mathrm{PBS} / \mathrm{BSA} / \mathrm{glucose}$ was added in the presence or absence of WGA $(50 \mu \mathrm{g} /$ $\mathrm{ml}$ ) for $30 \mathrm{~min}$ at $37^{\circ} \mathrm{C}$. Medium was then removed and $0.5 \%$ Triton $\mathrm{X}-100$ extraction buffer with $1 \mathrm{mM}$ PMSF was added at $4^{\circ} \mathrm{C}$ for $5 \mathrm{~min}$, and then the cells were washed three times for $1 \mathrm{~min}$ in Triton X-100-free extraction buffer. The extracted cells were fixed overnight in 1\% paraformaldehyde, $2 \%$ glutaraldehyde and $5 \%$ sucrose in PBS. The following day the coverslips were washed three times in PBS/glucose and twice in distilled $\mathrm{H}_{2} \mathrm{O}$ just prior to dipping in emulsion.

Autoradiographic procedures were essentially those described by Kopriwa and Leblond (1962). Coverslips were dipped into Kodak NTB2 nuclear emulsion, diluted $1: 1$ with distilled $\mathrm{H}_{2} \mathrm{O}$, and allowed to dry before being left to expose at $4^{\circ} \mathrm{C}$ for 17 days in the dark. The exposed coverslips were developed in Kodak D-19 developer for $2 \min$ at $21^{\circ} \mathrm{C}$, washed for $15 \mathrm{sec}$ in distilled $\mathrm{H}_{2} \mathrm{O}$, fixed for 2 min in Kodak Rapid Fixer, and washed with filtered water for $15 \mathrm{~min}$. The air-dried coverslips were mounted on glass slides with $50 \%$ glycerine and viewed with a Zeiss Universal microscope under phase and brightfield optics at $\times 200$ to 400 magnification.

Scanning electron microscopy. Cells were grown and treated with NGF as before for light microscopy. On day 9 , cells werc extracted in $0.5 \%$ Triton $X-100$ extraction buffer for $5 \mathrm{~min}$ at $4^{\circ} \mathrm{C}$, washed three times in Triton-X-100 minus extraction buffer, and fixed with $1 \%$ paraformaldehyde, $2 \%$ glutaraldehyde and $5 \%$ sucrose in PBS. After 5 min fixation, cells were washed three times for $1 \mathrm{~min}$ in PBS/0.1\% glucose, post-fixed in $2 \%$ osmium in 0.1 $M$ sodium phosphate (pH 7.4) for 30 min, rinsed three times more in PBS/ glucose, and then dehydrated through an acetone series. Coverslips with their overlay of extracted, fixed cells were critical point dried according to the method of Debault (1973) and then was coated with a 100-Ä-thick layer of gold in a sputtering device and viewed in an ISI-40 scanning electron microscope.

\section{Results}

Binding of ${ }^{125}$-NGF to PC12 Triton X-100 cytoskeletons. Schechter and Bothwell (1981) have shown that a portion of cell-bound ${ }^{125}$ NGF is not solubilized by Triton $X-100$. We have repeated this experiment and similarly found that about 15 to $20 \%$ of ${ }^{125}$-NGF binding pelleted with Triton X-100-insoluble material (Table I). We then investigated whether Triton X-100 cytoskeletons which were washed free of detergent and resuspended in PBS/BSA contain functional NGF receptors. NGF receptors in this Triton X-100-insolublc fraction would have to be attached to a very large structure in order for them to pellet at low centrifugal speeds $(500$ to $1000 \times g$ for $5 \mathrm{~min}$ ). Table I shows that Triton X-100 cytoskeletons prepared in this manner demonstrate 5 to $10 \%$ of the NGF binding activity of the cells from which they were derived. This value is 3-to 4-fold lower than if ${ }^{125}$ I-NGF were first bound to cells prior to Triton X-100 extraction.

Pretreatment of PC12 cells with WGA increases the NGF binding activity associated with the Triton X-100 cytoskeleton. As previously shown (Vale and Shooter, 1982; Grob and Bothwell, 1983) this lectin decreases NGF binding by $50 \%$ when added prior to ${ }^{125} \mathrm{I}-\mathrm{NGF}$, and the majority of this binding is not solubilized by Triton $X-100$. Table I also shows that Triton $X-100$ cytoskeletons prepared from WGAtreated cells contained almost 10 -fold the amount of NGF binding activity as those derived from untreated cells. In fact, WGA-treated intact cells and Triton X-100 cytoskeletons derived from these cells displayed similar levels of NGF binding. Therefore, unlike WGA- 
untreated cells, association of the receptor with the Triton $X-100$ cytoskeleton was not influenced by prior NGF binding in the presence of WGA. Receptor affinities were approximately the same in cells and Triton X-100 cytoskeletons (data not shown). ${ }^{125}$ I-NGF also bound to Triton $X-100$ cytoskeletons obtained from chick embryonic dorsal root ganglion cells and A875 cells, and binding, once again, was dramatically increased by pretreating these cells with WGA (data not shown).

In order to cause maximal association of the NGF receptor with Triton X-100-insoluble material, WGA must be added to cells prior to detergent extraction. Table II shows that WGA addition to Triton $X$-100-insoluble pellets did not cause a significant increase in NGF binding activity, indicating that the lectin is not merely activating masked receptors. WGA caused some NGF binding activity to pellet from detergent-soluble supernatants, but such binding was an order of magnitude lower than that found on cytoskeletons derived from WGA-treated cells. This effect could be due to the precipitation of soluble NGF receptors or small receptor-cytoskeleton complexes by WGA, a multivalent lectin. Interestingly, WGA addition to a combination of Triton $X$-100-soluble and -insoluble material caused a greater increase in pelletable binding than would be predicted on the basis of the lectin's effects on Triton X-100-soluble and -insoluble fractions separately. This finding implies that WGA causes an association of soluble NGF receptors with the Triton $X-100$-insoluble cytoskeleton, possibly due to crosslinking.

NGF receptors associated with the Triton X-100 cytoskeleton display slow dissociation kinetics. Two species of NGF receptors are found on PC12 cells: one a high affinity, slowly dissociating subtype and the other a low affinity, rapidly dissociating subtype (Landreth and Shooter, 1980). The two species can readily be distinguished, since ${ }^{125}$-NGF bound to rapidly dissociating receptors is completely released within 15 min upon adding excess unlabeled NGF, whereas ligand remains stably bound to the slowly dissociating receptor in this same time period. Table I shows that with $500 \mathrm{pM}$ ${ }^{125}$-NGF, approximately $25 \%$ of the total binding to whole cells was slowly dissociating. In contrast, under similar conditions, 70 to $100 \%$ of the total binding to Triton X-100 cytoskeletons was slowly dissociating. WGA increases the amount of slowly dissociating binding on cells by converting rapidly dissociating receptors into a slowly dissociating form which may or may not be cxactly the same as the naturally occurring slow receptor (Vale and Shooter, 1982), and it also increases in proportion the binding of ${ }^{125}$-NGF to the Triton $X$ 100 cytoskeleton. Once again, this binding was primarily slowly dissociating. Thus, the association of NGF receptors with the Triton $X-100$ cytoskeleton is correlated with a high affinity, slowly dissociating binding state of the receptor for NGF.

The time course of the appearance of rapidly and slowly dissociating binding in Triton X-100 cytoskeletons is shown in Figure 1. With WGA-pretreated preparations, maximum levels of rapidly dissociating binding were achieved after 5 min of ${ }^{125}$-NGF incubation. In contrast, slowly dissociating binding developed more gradually, reaching a steady state after 30 to 60 min. For Triton X-100 cytoske-

TABLE I

Binding of ${ }^{125}$-NGF to cells and Triton X-100 cytoskeletons

PC12 cells $\left(0.75 \times 10^{6} / \mathrm{ml}\right)$ were incubated with and without WGA $(50 \mu \mathrm{g} / \mathrm{ml})$ for $30 \mathrm{~min}$ at $37^{\circ} \mathrm{C}$. These cell samples were divided into equal aliquots and centrifuged at $500 \times g$ for $5 \mathrm{~min}$. Cell pellets were then either resuspended in binding buffer or extracted with Triton $X$ - 100 extraction buffer for 5 min at $4^{\circ} \mathrm{C}$. Cells or cytoskeletons were then centrifuged $\left(1000 \times g ; 5 \mathrm{~min}\right.$ at $\left.4^{\circ} \mathrm{C}\right)$, and supernatants were removed. Pellets were washed twice and resuspended in their original volume of binding buffer. ${ }^{125}$-NGF ( $580 \mathrm{pM}$ ) was added to cells or cytoskeletons for $45 \mathrm{~min}$ at $37^{\circ} \mathrm{C}$, and total, slowly dissociating, and Tritur $X-100$-insoluble (in the case of intact cells) binding were measured.

\begin{tabular}{|c|c|c|c|c|c|c|}
\hline \multirow{3}{*}{ Sample } & \multirow{3}{*}{ Centrifugate } & \multicolumn{5}{|c|}{ 125I-NGF Binding } \\
\hline & & \multirow{2}{*}{$\begin{array}{c}\text { Total } \\
\left.\text { (fmol/106 } 10^{6} \mathrm{cells}\right)\end{array}$} & \multicolumn{2}{|c|}{ Slowly Dissociating } & \multicolumn{2}{|c|}{ Triton $X-100$ Insoluble } \\
\hline & & & $\begin{array}{c}\mathrm{fmol} / 10^{\circ} \\
\text { cells }\end{array}$ & $\%$ Total & fmol $/ 10^{6}$ cells & $\%$ Total \\
\hline$-W G A$ & $\begin{array}{l}\text { Cells } \\
\text { Cytoskeletons }\end{array}$ & $\begin{array}{r}217 \pm 5 \\
12 \pm 2\end{array}$ & $\begin{array}{r}57 \pm 1 \\
9 \pm 3\end{array}$ & $\begin{array}{l}26 \\
75\end{array}$ & $43 \pm 8$ & 20 \\
\hline$+W G A$ & $\begin{array}{l}\text { Cells } \\
\text { Cytoskeletons }\end{array}$ & $\begin{array}{l}136 \pm 2 \\
112 \pm 20\end{array}$ & $\begin{array}{r}103 \pm 1 \\
80 \pm 16\end{array}$ & $\begin{array}{l}76 \\
71\end{array}$ & $108 \pm 6$ & 79 \\
\hline
\end{tabular}

TABLE ॥

Maximal association of the NGF receptor with the Triton $X-100$ cytoskeleton requires WGA addition to cells prior to extraction

PC12 cells $\left(4 \times 10^{6} / \mathrm{ml}\right)$ were centrifuged and resuspended in Triton X-100 extraction buffer (in an equal volume) for 5 min at $4^{\circ} \mathrm{C}$. Triton $X-100$ cytoskeletons were centrifuged at $1000 \times g$ for $5 \mathrm{~min}$ at $4^{\circ} \mathrm{C}$ and the supernatant was removed and saved (Supernatant). The pellet was resuspended in a volume equal to that of the supernatant of Triton X-100 extraction buffer (Pellet). Another sample (Pellet and Supernatant) underwent identical Triton X-100 extraction; however, the pellet and supernatant were resuspended together instead of being separated after centrifugation. Triton $X-100$ Pellets, Supernatants and Pellets, plus Supernatants were divided equally and one-half received WGA $(50 \mu \mathrm{g} / \mathrm{ml})$ for $30 \mathrm{~min}$ at $23^{\circ} \mathrm{C}$. All samples were then centrifuged (1000 $\times$ $g$ for $5 \mathrm{~min}$ at $4^{\circ} \mathrm{C}$ ), and the pellets were washed twice and resuspended in the original volume of PBS/BSA. An equal volume of ${ }^{125}$-NGF in PBS/BSA was added (final concentration, $600 \mathrm{pM}{ }^{125} \mathrm{I}-\mathrm{NGF}$ with $2 \times 10^{6}$ /Triton X-100 cytoskeleton/ml) and incubated for 45 min at $37^{\circ} \mathrm{C}$ prior to assaying pelletable ${ }^{125}$ NGF binding in a Microfuge. Nonspecific ${ }^{125}$-NGF binding was treated in the manner described above. ${ }^{125}$-NGF binding is expressed in femtomoles bound to material from Pellets, Supernatants, or Pellets and Supernatants from $2 \times 10^{6} / \mathrm{ml}$ of Triton X-100-extracted cells. For comparison, it is also expressed as the percentage of NGF binding to $2 \times 10^{6} / \mathrm{ml}$ of Triton $\mathrm{X}-100$ cytoskeletons derived from cells treated with $50 \mu \mathrm{g} / \mathrm{mi}$ of WGA for $30 \mathrm{~min}$ at $23^{\circ} \mathrm{C}$ prior to detergent extraction.

\begin{tabular}{|c|c|c|c|c|}
\hline \multirow{3}{*}{ Sample } & \multicolumn{4}{|c|}{${ }^{125}$ |-NGF Binding } \\
\hline & \multicolumn{2}{|c|}{-WGA } & \multicolumn{2}{|c|}{ +WGA } \\
\hline & $\begin{array}{c}\mathrm{fmol} \\
\text { (from } 2 \times 10^{6} \text { cells) }\end{array}$ & $\%$ of WGA-pretreated Cells & $\begin{array}{c}\text { fmol } \\
\text { (from } 2 \times 10^{6} \text { cells) }\end{array}$ & $\%$ of WGA-pretreated Cells \\
\hline Triton $X-100$ pellet & $16.3 \pm 4.1$ & 6 & $25.0 \pm 2.2$ & 10 \\
\hline Triton $X-100$ supernatant & $0.3 \pm 0.2$ & 1 & $7.7 \pm 1.5$ & 3 \\
\hline Triton $X-100$ pellet and supernatant & $12.8 \pm 5.8$ & 5 & $63.3 \pm 4.6$ & 25 \\
\hline
\end{tabular}




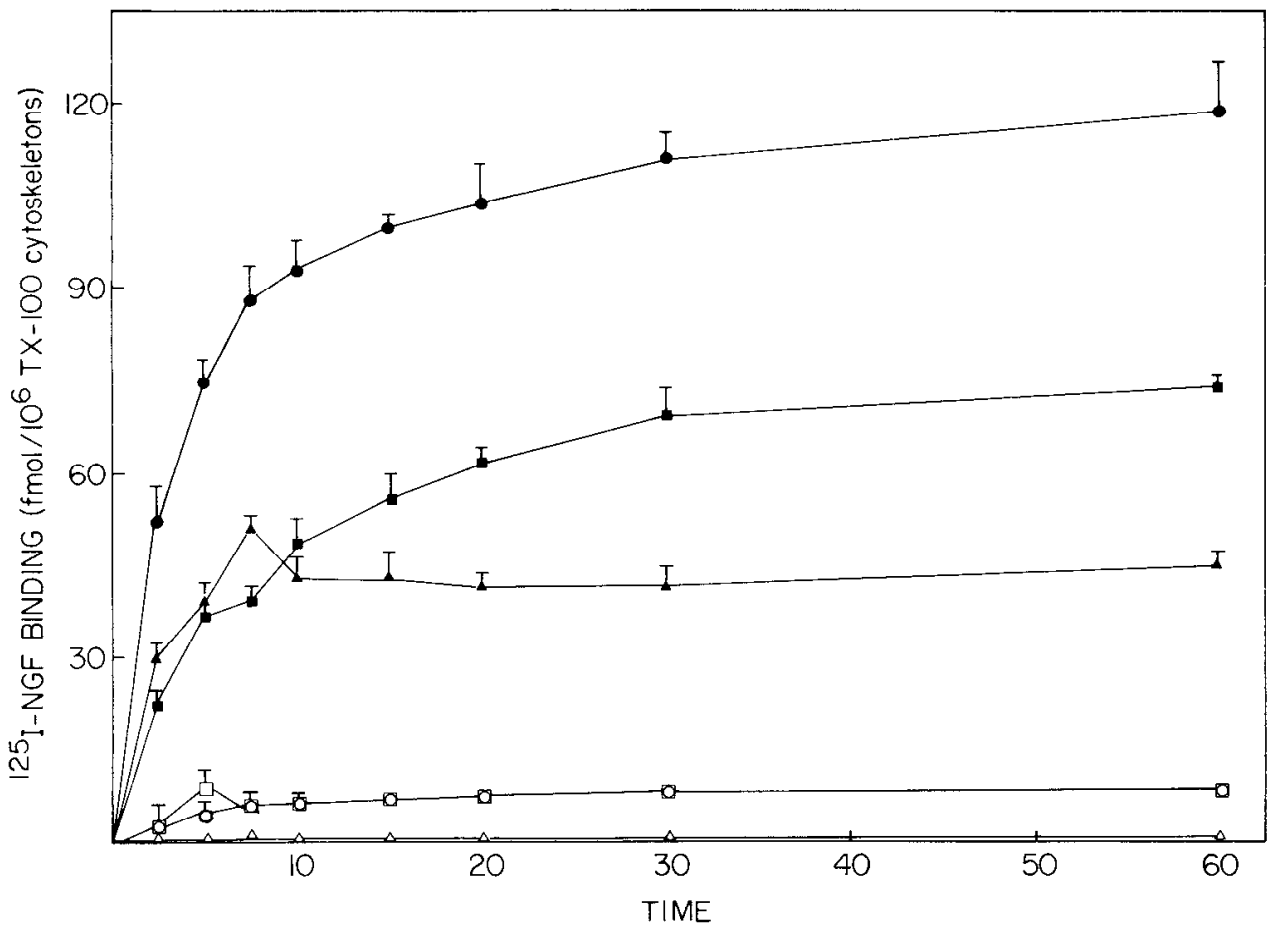

Figure 1. Time course of ${ }^{125} \mid$-NGF binding to Triton $X-100$ cytoskeletons. Triton $X-100$ cytoskeletons were prepared from $\mathrm{PC} 12$ cells $\left(1.5 \times 10^{6} / \mathrm{ml}\right)$ which were previously treated with (solid symbols) or without (open symbols) WGA $(50 \mu \mathrm{g} / \mathrm{ml}$ ) for $30 \mathrm{~min}$ at $37^{\circ} \mathrm{C}$. ${ }^{125}$-NGF $(610 \mathrm{pm})$ was added to Triton $X-100$ cytoskeletons, and at the indicated time total $(\mathbf{O}, 0)$, slowly dissociating $(\boldsymbol{\square}, \square)$, and rapidly dissociating $(\boldsymbol{\Lambda}, \Delta)$ binding were determined. Error bars indicate standard deviations.

letons prepared without WGA pretreatment, virtually all of the binding in this experiment was slowly dissociating. Binding to this receptor was again slower than that to the rapidly dissociating receptor in the presence of WGA. Thus, the time course of binding to the two receptor subtypes shows the same differences as those found in intact cells (Landreth and Shooter, 1980; Valc and Shooter, 1982). Since there is no plasma membrane, the time-dependent development of slowly dissociating binding in Triton X-100 cytoskeletons cannot be explained by internalization.

Triton X-100 extraction of cell surface proteins. Is the association of the NGF receptor with the Triton X-100 cytoskeleton induced by WGA unique, or are other membrane proteins affected in a similar fashion? To answer this question, we labeled cell surface proteins in a general manner with 125 using a lactoperoxidase-catalyzed reaction and then examined the Triton $X-100$ solubility of these labeled proteins. Figure 2 shows that $33 \%$ of the ${ }^{125}$-labeled cell surface proteins of PC12 cells remained associated with the cytoskeleton after Triton $X-100$ extraction. This value is more than 2 -fold lower than the Triton $X-100$ insolubility of membrane proteins on cultured fibroblasts obtained by Ben Ze'ev et al. (1979). Despite the dramatic effects of WGA on the Triton X-100 solubility of the NGF receptor on $\mathrm{PC} 12$ cells, the lectin only increased by $7 \%$ the Triton $X-100$ insolubility of ${ }^{125}$-labeled cell surface proteins. Con $A$, a lectin which recognizes mannose residues, had an effect similar to that of WGA.

Only a fraction of the total membrane-bound proteins contain carbohydrate moieties which will interact with WGA. Therefore, we investigated the Triton $X-100$ solubility of WGA receptors using an iodinated WGA derivative. ${ }^{125} \mathrm{I}-\mathrm{WGA}(0.1 \mu \mathrm{g} / \mathrm{ml})$ was added to $\mathrm{PC} 12$ cells along with increasing concentrations of unlabeled WGA, and samples were centrifuged through Triton X-100 extraction buffer to determine the detergent solubility of the bound ligand. Figure 3 shows that, with $0.1 \mu \mathrm{g} / \mathrm{ml}$ of ${ }^{125} \mathrm{I}-\mathrm{WGA}, 80 \%$ of the cell-bound ${ }^{125}$ WGA was solubilized by Trilon $X-100$. However, increasing the receptor occupancy of WGA receptors by adding unlabeled WGA resulted in a decrease in the Triton X-100 solubility of the cell-bound tracer ${ }^{125} \mathrm{I}$-WGA. Greater than 90\% detergent insolubility was achieved at WGA concentrations in excess of $33 \mu \mathrm{g} / \mathrm{ml}$. The NGFreceptor complex is converted to a Triton X-100-insoluble form at similar WGA concentrations (data not shown). This result indicates that most WGA-binding glycoproteins are unattached to the cyto-

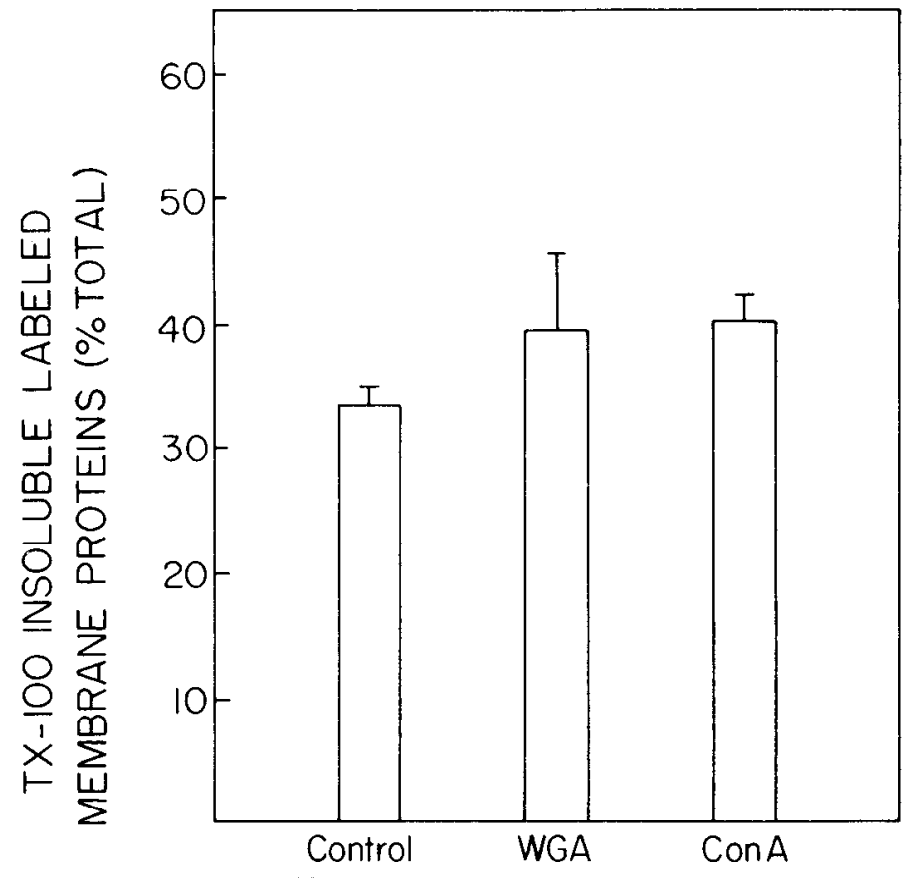

Figure ?. Triton X-100 solubility of lactoperoxidase-labeled cell surface proteins. PC12 cell surface proteins were labeled by lactoperoxidase as described under "Materials and Methods." Labeled cells (diluted to $0.5 \times$ $10^{6} / \mathrm{ml}$ ) were incubated without lectins or with $50 \mu \mathrm{g} / \mathrm{ml}$ of either WGA or Con $\mathrm{A}$ for $30 \mathrm{~min}$ at $37^{\circ} \mathrm{C}$. Cells were centrifuged $(500 \times \mathrm{g} ; 5 \mathrm{~min})$, supernatants were removed, and cells were resuspended in Triton X-100 extraction buffer for 5 min at $4^{\circ} \mathrm{C}$. Radioaclivity associated with the Triton $X$ 100 cytoskeleton was assayed by centrifugation through $0.15 \mathrm{M}$ sucrose buffer as described for ${ }^{125} \mathrm{l}$-NGF binding. Histograms show the percentage of radioactivity associated with the Triton $\mathrm{X}-100$ cytoskeleton, and error bars indicate standard deviations.

skeleton but become associated with the Triton $X-100$ cytoskeleton by increasing the concentration of cell-bound WGA. The dependence upon WGA concentration for eliciting this effect suggests that this phenomenon may be the result of crosslinking cell surface proteins. 
The Triton X-100 solubility of WGA receptors and the conversion of NGF receptors to a slowly dissociating state exhibited similar WGA dose response curves (Fig. 3). At $10 \mu \mathrm{g} / \mathrm{ml}$ of WGA, $80 \%$ of NGF receptors were in a slowly dissociating state, and the same proportion of WGA receptors was also Triton X-100 insoluble. These results suggest that the Triton $X-100$ insolubility of WGA receptors after lectin binding may in some way be related to the change in the binding properties of the NGF receptor.

Composition of the Triton $X-100$ cytoskeleton. The morphology of the Triton $X-100$-insoluble material from PC12 cells was examined by scanning electron microscopy. Figure 4 shows a micrograph of PC12 cells, which have developed neurites after a 9-day exposure to NGF, after detergent extraction. Membrane structure was lost, and left behind was a nuclear remnant and an array of cytoskeletal filaments. Similar morphologies of Triton X-100 cytoskeletons are found with other cell types as well (Ben-Ze'ev et al., 1979; Burridge et al., 1982a, b). A latticework of filaments was also observed along the neurites and in the growth cones. Higher magnification views show that the cytoskeleton of delergent-exlracted PC12 cells forms a discrete boundary at what was once the plasma membrane.

Approximately 65 to $75 \%$ of PC12 proteins were solubilized by Triton $X-100$. Some of the prominent proteins left behind in the Triton $X-100$-insoluble residue co-migrated in a polyarcylamide gel under denaturing and reducing conditions with the low molecular weight histones $\left(M_{\mathrm{r}}=16,000\right.$ and 18,000$)$, histone $\mathrm{H} 1\left(M_{\mathrm{r}}=31,000\right)$, actin $\left(M_{\mathrm{r}}=43,000\right)$, tubulin $\left(M_{\mathrm{r}}=55,000\right)$, myosin $\left(M_{\mathrm{r}}=200,000\right)$, and some higher molecular weight proteins $\left(M_{r}=200,000\right)$ which may be actin-associated proteins (data not shown). WGA treatment of cells did not affect the protein pattern of the Triton X-100-insoluble residue.

Localization of NGF binding in the Triton X-100 cytoskeleton. Nuclear material is a prominent constituent of the Triton $X-100$ cytoskeleton and could play a role in the association of the receptor with detergent-insoluble material. To investigatc this possibility, Triton X-100 solubility of NGF binding to enucleated PC12 cells was

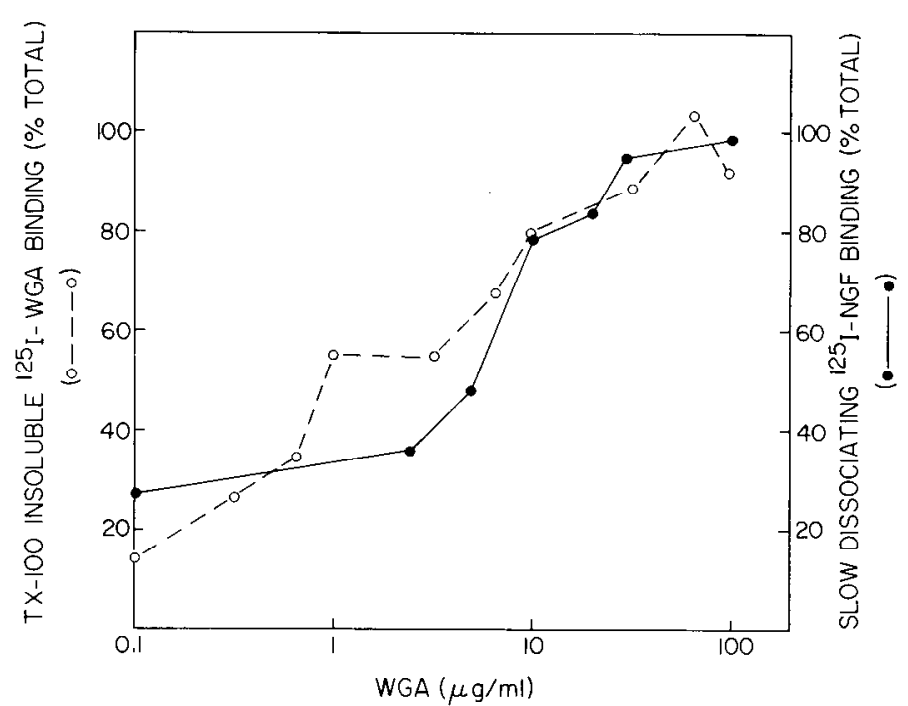

Figure 3. Concentration dependence of Triton $X-100$ insolubility of ${ }^{125}$ WGA binding and WGA-induced NGF receptor conversion. In one experiment (O), tracer ${ }^{125} \mathrm{l}$-WGA $(0.1 \mu \mathrm{g} / \mathrm{ml})$ was added to PC12 cells $\left(10^{6} / \mathrm{ml}\right)$ along with increasing concentrations of unlabeled WGA. Nonspecific ${ }^{125}$-WGA binding was determined by adding $100 \mathrm{~mm} \mathrm{~N}$-acetyl-D-glucosamine to the PBS/BSA/ glucose solution. After a $45-\mathrm{min}$ incubation at $37^{\circ} \mathrm{C}$, total and Triton $\mathrm{X}-100-$ insoluble binding were assayed in the same manner described for ${ }^{125}$-NGF binding. The percentage of Triton X-100-insoluble ${ }^{125}$ I-WGA binding of the total is indicated over a range of WGA concentrations (combination of labeled and unlabeled ligand). In a separate experiment (O), ${ }^{125}$ I-NGF (500 pM) was added to PC12 cells for 30 min at $37^{\circ} \mathrm{C}$. WGA was then added at the indicated concentration for an additional 30 min prior to assaying total and slowly dissociating binding. The percentage of slowly dissociating ${ }^{125}$ NGF binding of the total is expressed at each WGA concentration. examined. Nuclei were removed from PC12 cells by cytochalasin B treatment followed by centrifugation. Cytoplasts derived by this procedure are viable for 1 to 2 days and are capable of extending neurites in response to NGF treatment (Nicholls et al., 1981). Figure 5 shows that cytoplasts bind ${ }^{125} \mathrm{~F}-\mathrm{NGF}$, although to a lesser extent than intact cells. The lower level of binding is very likely due to partitioning of a portion of the plasma membrane to the nucleoplast as it pinches off during centrifugation. WGA converted ${ }^{125}$-NGF binding to a slowly dissociating state both on cytoplasts and whole cells. Furthermore, $25 \%$ of the total binding to cytoplasts was Triton $X-100$ insoluble, and WGA increased this proportion to $>80 \%$. This result argues that the nucleus cannot be exclusively involved in the association of NGF receptors with Triton X-100-insoluble material.

The distribution of NGF receptors in the Triton X-100 cytoskeleton of differentiated PC12 cells can be visualized by light microscopic autoradiography. In this experiment, differentiated PC12 cells (treated with NGF for several days to induce neurites) were incubated with ${ }^{125}$ I-NGF and co-treated with or without WGA. Intact cells treated this way were labeled to roughly the same extent regardless of the presence or absence of WGA (Fig. 6, A and C). However, when ${ }^{125}$ I-NGF/WGA-treated cells were extracted with Triton $X-100$, heavy labeling over neurites and growth cones was retained (Fig. 6D). Conversely, when ${ }^{125}$-NGF was presented to cells without the simultaneous addition of WGA, the resultant Triton $X-100$-extracted cell ghosts were only lightly labeled in perinuclear regions, with little binding retained on the processes or growth cones (Fig. 6B). With longer exposure times it was possible to detect some cytoskeletal binding on the neurites and growth cones, confirming both the existence of high affinity receptors in these regions (Carbenetto and Stach, 1972; M. J. Ignatius and E. M. Shooter, unpublished observations) and their association with the cytoskeleton, an association that is dramatically increased with WGA treatment.

\section{Discussion}

NGF receptors exist in two different binding states. Covalent crosslinking of ${ }^{125}$ I-NGF to PC12 cell surfaces (Hosang and Shooter, 1985) and selective trypsin sensitivity of binding (Landreth and Shooter, 1980; Schechter and Bothwell, 1981) indicate that slowly and rapidly dissociating bindings correlate with distinct structural or conformational receptor entities. This situation could arise with two discrete receptor proteins or a single proleir capable of interconversion between two binding states. Evidence has been put forth in support of this latter hypothesis (Vale and Shooter, 1982, 1983; Buxser et al, 1983; Grob and Bothwell, 1983). From our results and those of Schechter and Bothwell (1981), one manifestation of the differences between the two receptor subtypes is their differential extraction by Triton $X-100$.

Many findings indicate that the correlation between slowly dissociating and Triton X-100-insoluble NGF binding is more than coincidental. Agents which increase the proportion of slowly dissociating binding such as WGA (Vale and Shooter, 1982; Buxser et al., 1983; Grob and Bothwell, 1983) and anti-NGF antibodies (Vale and Shooter, 1983) also enhance the resistance of binding to detergent solubilization. In the instance of WGA, time courses of the increase in slowly dissociating and Triton X-100-insoluble binding after lectin addition are superimposable (Valc and Shooter 1982). Recently, Jesaitis et al. (1984) have also observed that formation of a slowly dissociating complex between the $\mathrm{N}$-formyl chemotactic peptide and its receptor on human granulocytes is accompanied by a change in the detergent solubility of the ligand-receptor complex. These investigators have also suggested that an association of the receptor with the cytoskeleton is involved in modulation of its affinity and possibly in its subsequent internalization.

Curiously, although present both in Triton X-100 cytoskeletons and whole cells, slowly dissociating binding is present in very low amounts in preparations of PC12 plasma membranes (Block and Bothwell, 1983). This result cannot be accounted for simply by receptor loss, since slowly dissociating binding can be regained by 

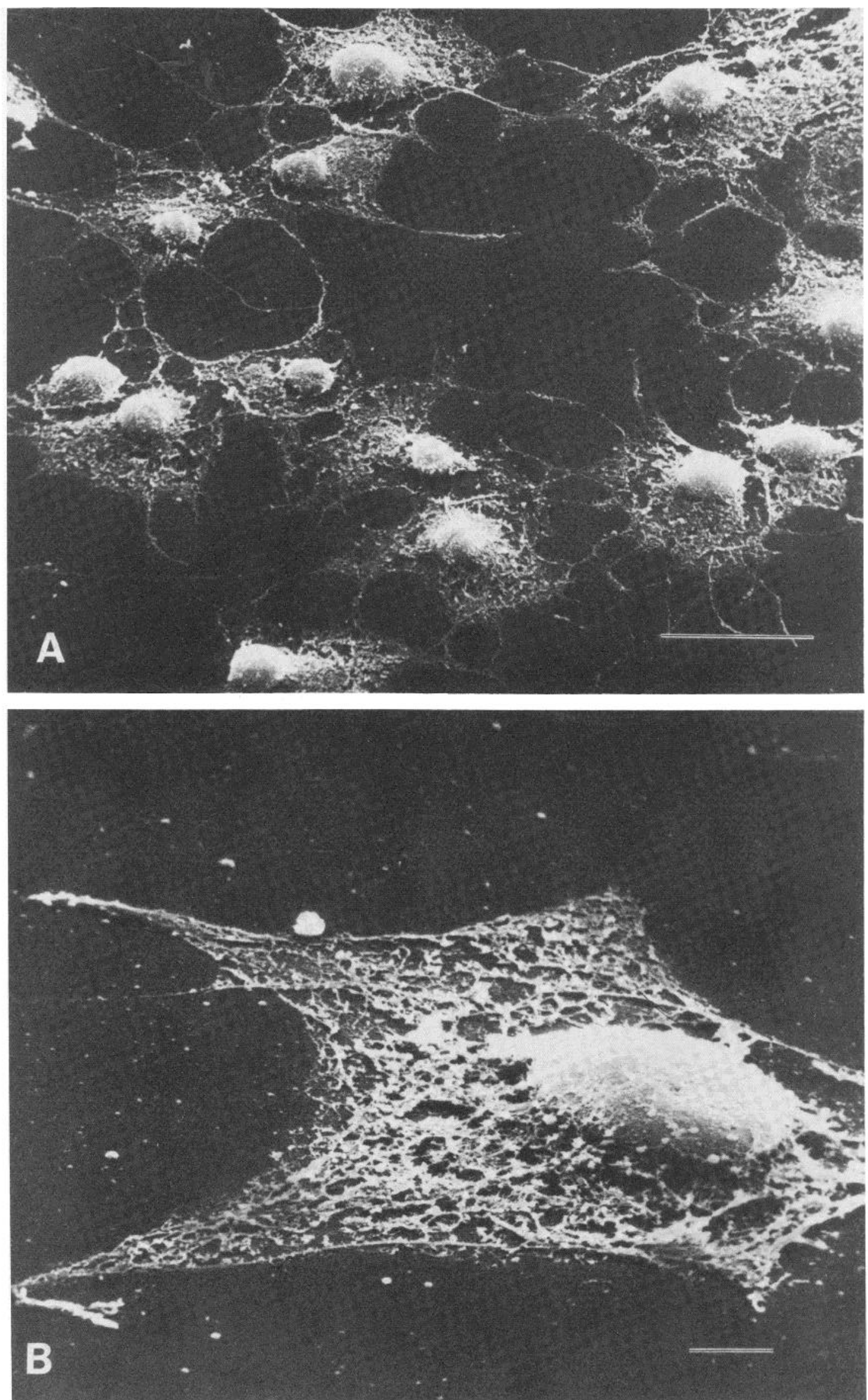

Figure 4. Scanning electron microscopy of PC12 Triton X-100 cytoskeletons. PC12 cells were grown on plastic coverslips and treated with NGF (50 ng/ $\mathrm{ml}$ ) for 5 days to induce neurites. Differentiated cells were washed twice with binding buffer and incubated with $0.5 \%$ Triton X-100 extraction buffer for 5 $\min$ at $4{ }^{\circ} \mathrm{C}$. Cytoskeletons were washed twice, fixed with $1 \%$ paraformaldehyde and $2 \%$ glutaraldehyde, and prepared for scanning electron microscopy as described under "Materials and Methods." All that remains of the cells after extraction are the nucleus, cytoskeleton, and a few Triton-resistant organelles. Scale bars: $A, 10 \mu \mathrm{m} ; B, 0.1 \mu \mathrm{m}$. 


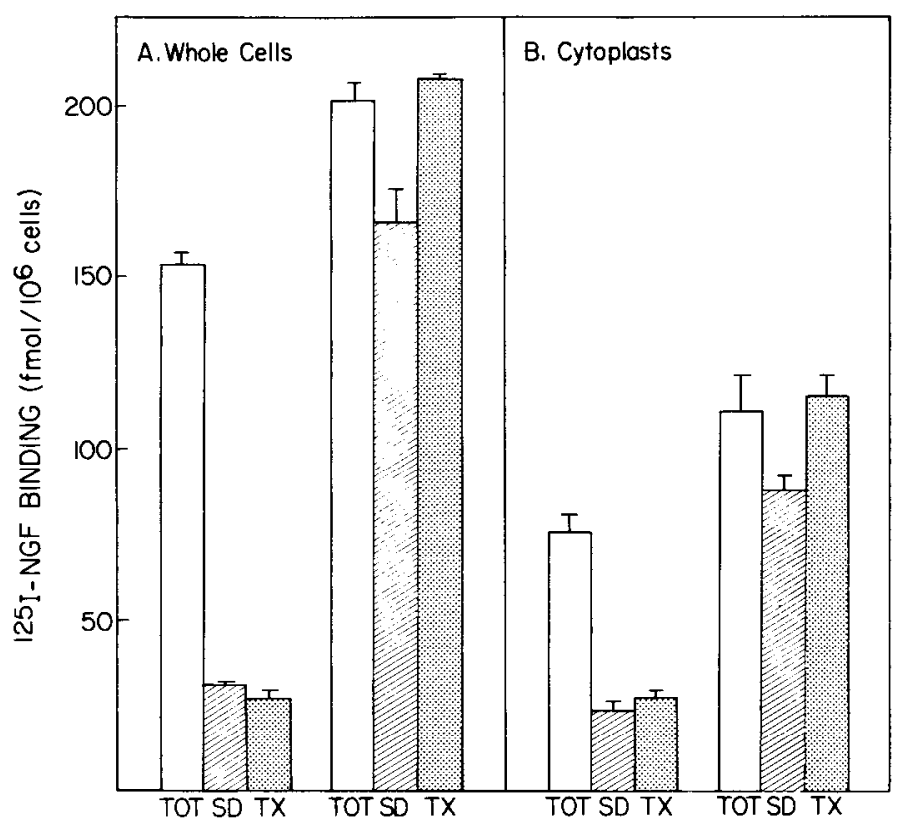

Figure 5. Effects of WGA on ${ }^{125}$-NGF binding to enucleated cells. PC12 cytoplasts were obtained as described under "Materiais and Methods." 125NGF (1 IIM) was added to cells $(A)$ or cytoplasts $(B)$ for $30 \mathrm{~min}$ at $37^{\circ} \mathrm{C}$. Half of each sample then received WGA $(50 \mu \mathrm{g} / \mathrm{ml})$ for an additional $30 \mathrm{~min}$ prior to being assayed for total $(T o t)$, slowly dissociating $(S D)$, and Triton X-100insoluble $(T X)$ binding.

fusion of PC12 membranes with 3T3 cells which do not normally display NGF receptors (Block and Bothwell, 1983). Solubilized receptors also release bound NGF exclusively by rapidly dissociating kinetics (Buxser et al., 1983). These results imply that some element in whole cells or Triton X-100 cytoskeletons confers a high affinity, slowly dissociating state to the NGF receptor. A prominent candidate for performing this role is the cytoskeleton or a cytoskeleton-associated protein.

A number of membrane proteins have been reported to interact with cytoskeleton by various biochemical criteria (see Branton et al., 1981; Mescher et al., 1981; Pober et al., 1981; Carraway et al., 1983, for examples). Furthermore, an association between actin and intermediate filaments and the plasma membrane has been visualized by electron microscopy (Condeelis, 1979; Hubbard and $\mathrm{Ma}$, 1983). At present, it is prudent to mention that evidence of a linkage between the NGF receptors and cytoskeletal proteins is circumstantial. We have shown that NGF receptors are present in a detergentinsoluble struclure composed of cyloskeletal proteins and a nuclear remnant that allows the receptor to be pelleted at very low centrifugal forces. This association is also found in enucleated cells, suggesting that the nucleus is not solely responsible for this phenomenon. Also, NGF receptors can be induced with WGA to associate with the Triton X-100-insoluble residue corresponding to neurites and growth cones, regions which consist primarily of cytoskeletal elements. Furthermore, in preliminary results, we found that NGF receptors are partially released from the detergent-insoluble residue by agents which disrupt the cytoskeleton such as $0.4 \mathrm{M} \mathrm{KCl}, 10-\mathrm{sec}$ sonication, and DNase I, an actin-depolymerizing agent. Cytochalasin $\mathrm{B}$ and colchicine had no effect, however. Nonetheless, the only way to convincingly demonstrate a linkage with the cytoskeleton is to document the co-sedimentation of the receptor with cytoskeletal proteins. In addition, our results do not rule out the possibility that the nucleus, in addition to the cytoskeleton, plays a role in the association of NGF receptor with the Triton X-100-insoluble residue, as has been previously proposed (Yankner and Shooter, 1979).

How is the interaction of the receptor and the cytoskeleton regulated? One possibility is that NGF may promote an association between the receptor and cytoskeleton. In support of this notion, we found that Triton $X-100$ insolubility of the receptor is greater when it is occupied with NGF before extraction (Table I). Conversely, WGA treatment of cells causes a maximal association of the receptor with the cytoskeleton whether or not NGF is present prior to detergent extraction. Modulation of the association of membranc protcins with the cytoskeleton by lectins has also been reported by several investigators. Actin and myosin have been localized under lectininduced patches and caps of membrane glycoproteins in lymphocytes (Bourguignon and Singer, 1977) and Dictyostelium (Condeelis, 1979). Also, Con A-induced interactions between two platelet glycoproteins (Painter and Ginsberg, 1982) and three neutrophil cell surface proteins (Sheterline and Hopkins, 1981) and the cytoskeleton have been documented. Lectin-induced crosslinking of proteins appears important for this effect, since a succinylated Con A derivative which is functionally monovalent docs not changc substantially the detergent solubility of such proteins. Antibody-induced crossbridging of cell surface proteins such as surface lgG on lymphocytes (Flanagan and Koch, 1978; Woda and McFadden, 1983) also induces cytoskeletal attachment. We have observed a similar phenomenon with anti-NGF antibodies which caused NGF-receptor complexes to co-sediment with the Triton $\mathrm{X}$-100-insoluble residue (Vale and Shooter, 1983). This response was due to antibody-induced crosslinking since monovalent Fab fragment had no effect.

The mechanism by which crosslinking of cell surface proteins causes their association with the cytoskeleton is unclear. Binding of a lectin to certain glycoproteins could cause a conformational change sufficient to induce a direct transmembrane interaction with the cytoskeleton; however, our results show that all receptors for WGA, not a subset, are rendered insoluble to Triton X-100 in a manner dependent upon the concentration of lectin added. This finding implies some sort of cooperative interaction between occupied WGA receptors which makes them detergent insoluble. Studies which observed attachments of only certain glycoproteins with the cytoskeleton by Con A may have been limited by the ability to detect only the most abundant lectin receptors (Sheterline and Hopkins, 1981; Painter and Ginsberg, 1982).

Three explanations are consistent with the results we have obtained. The first is that the restriction of lateral mobility of glycoproteins by lectin-induced crosslinking (Schlessinger et al., 1977; Koppel et al., 1981) enhances their interaction with the underlying cytoskeletal network. An alternative possibility is that patches of crosslinked membrane proteins produce strong lipid-protein interactions sufficient to prevent detergent extraction of these membrane domains. In support of this view, Condeelis (1979) found that membrane in regions containing clustered Con A-receptor complexes is more resistant to disruption by Triton $X-100$. These areas also contain large amounts of attached actin and myosin which may contribute to the association of Con A receptors with detergent-insoluble material. The third hypothesis, which we favor, is that a subset $(<20 \%)$ of the lectin receptors is associated with the cytoskeleton and that lectin addition serves to crosslink these proteins to others that are normally unrestrained in the lipid bilayer, thereby making all occupied lectin-binding proteins Triton $X-100$ insoluble. A similar conclusion concerning the mechanism of Con A-induced attachment of glycoproteins to the cytoskeleton was reached by Jung et al. (1984), who showed that Con A crossbridged unattached glycoproteins to a glycoprotein which is strongly associated with the submembrane cytoskeleton.

An interaction of the NGF receptor with the cytoskeleton could have several important consequences for the action of this hormone. Although the mechanism by which NGF affects the differentiated state of responsive cells is unknown, dose response curves indicate that these effects are mediated by high affinity, slowly dissociating receptors (Sutter et al., 1979b). NGF also influences the cytoskeletal organization of PC12. Within $30 \mathrm{sec}$ after addition, NGF induces prominent cell surface ruffling (Connolly et al., 1979), whereas at later times, reorganization of microfilaments and microtubules oc- 

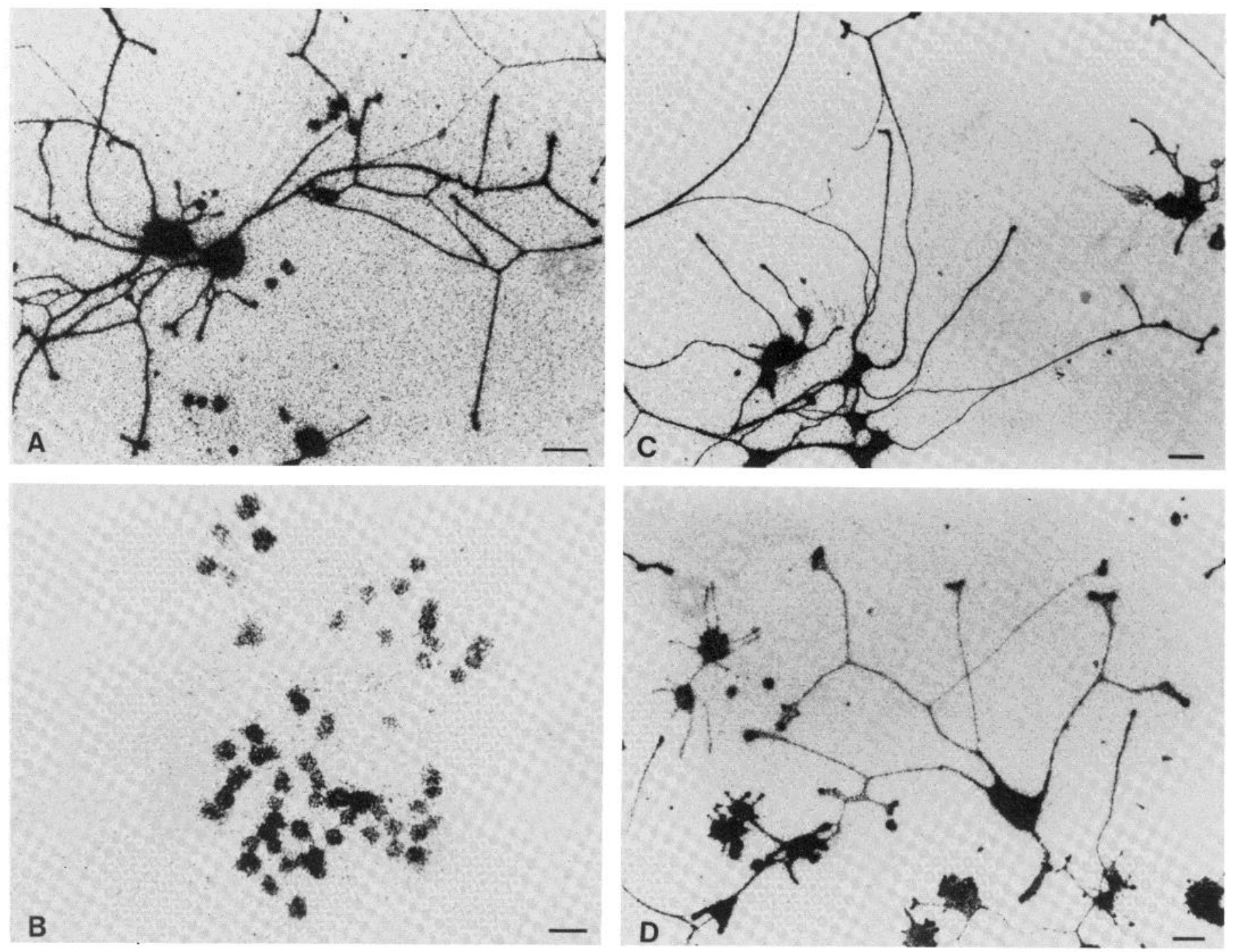

Figure 6. Autoradiography of Triton X-100-insoluble ${ }^{125}$-NGF binding to differentiated PC12 cells. Cells were grown for 8 days in NGF. On day 9 cells were washed three times for $1 \mathrm{hr}$ with NGF-free medium; then, ${ }^{125} \mathrm{INGF}(1 \mathrm{nM})$ was added in the presence or absence of WGA (50 $\left.\mu \mathrm{g} / \mathrm{ml}\right)$ for $30 \mathrm{~min}$ at $37^{\circ} \mathrm{C}$. The cells were then either left intact or extracted in $0.5 \%$ Triton X-100 extraction buffer for 5 min at $4^{\circ} \mathrm{C}$ and subsequently washed. (See scanning electron micrographs of Fig. 4, for structures that remain after identical treatment.) After fixation and processing for autoradiography (see "Materials and Methods"), the Triton X-100 cytoskeletons were photographed with brightfield optics. Treatments were as follows: $A,{ }^{125}$-NGF alone; $B$, ${ }^{125}$-NGF and Triton $X-100, C,{ }^{125}$-NGF and WGA; and $D,{ }^{125}$-NGF, WGA, and Triton X-100. WGA has no effect on the total labeling seen on intact cells $(A$ and $C)$, whereas on extracted cells $(B$ and $D)$ WGA pretreatment results in the retention of heavy labeling over the cytoskeletal-rich neurites and growth cones $(D)$ compared to only minimal perinuclear labeling seen without WGA $(B)$. Scale bars, $10 \mu \mathrm{m}$.

curs, culminating in the outgrowth of neurites. Furthermore, binding of NGF to receptors at growth cones redirects the orientation of these structures in a chemotactic fashion even in the absence of a connection with the cell body (Gundersen and Barrett, 1979; Seeley and Greene, 1983). Interaction between slowly dissociating receptors and the cytoskeleton may be involved in mediating these responses.

Furthermore, NGF receptors undergo cell surface clustering and subsequent internalization (Levi et al., 1980), and several studies indicate that the slowly dissociating receptor is the species which becomes internalized (Yankner and Shooter, 1982; Bernd and Greene, 1983). Attachments between cell surface proteins and cytoskeletal filaments have been implicated in the internalization process (Salisbury et al., 1980). To obtain more detailed knowledge of the differences between rapidly and slowly dissociating receptors and their possible interactions with the subcortical cytoskeleton, it will be necessary to reconstitute such functions or interactions with isolated membranes or purified receptors (Puma et al., 1983) in liposomes. Such experiments may help in defining some of the initial events in the mechanism of action of this hormone.

\section{References}

Ben-Ze'ev, A., A. Duerr, F. Solomon, and S. Penman (1979) The outer boundary of the cytoskeleton: A lamina derived from plasma membrane proteins. Cell 17: 859-865.

Bennett, V. (1982) The molecular basis for membrane-cytoskeleton association in human erythrocytes. J. Cell. Biochem. 18: 49-65.

Bernd, P. S., and L. A. Greene (1983) Association of ${ }^{125}$-NGF with PC12 pheochromocytoma cells: Evidence for internalization via high-affinity receptors only and for long-term regulation by NGF of both high- and lowaffinity receptors. Soc. Neurosci. Abstr. 9: 842.

Block, T., and M. Bothwell (1983) The nerve growth factor receptor on PC12 cells: Interconversion between two forms with different binding properties. J. Neurochem. 40: 1654-1663.

Bourguignon, L. Y. W., and S. J. Singer (1977) Transmembrane interactions and the mechanism of capping of surface receptors by their specific ligands. Proc. Natl. Acad. Sci. U. S. A. 74: 5031-5035. 
Branton, D., C. M. Cohen, and J. Tyler (1981) Interaction of cytoskeletal proteins on the human erythrocyte membrane. Cell $24: 24-32$

Bray, D., and D. Gilbert (1981) Cytoskeletal elements in neurons. Annu. Rev. Neurosci. 4: 505-523.

Brown, S., W. Levinson, and J. A. Spudich (1976) Cytoskeletal elements of chick embryo fibroblasts revealed by detergent extraction. J. Supramol. Struct. 5: 119-130.

Burridge, K., T. Kelley, and L. Connell (1982a) Proteins involved in the attachment of actin to the plasma membrane. Philos. Trans. R. Soc. Lond. (Biol.) 299: 291-299.

Burridge, K., T. Kelley, and P. Mangeat (1982b) Nonerythrocyte spectrins: Actin-membrane attachment proteins occurring in many cell types. J. Cell Biol. 95: 478-486.

Buxser, S. E., D. J. Kelleher, L. Watson, P. Puma, and G. L. Johnson (1983) Change in state of nerve growth factor receptor. Modulation of receptor affinity by wheat germ agglutinin. J. Biol. Chem. 258: 3741-3749.

Carbonetto, S. T., and R. W. Stach (1980) Localization of nerve growth factor bound to cultured sensory neurons. Soc. Neurosci. Abstr. 6: 375.

Carraway, C. A. C., G. Jung, and K. L. Carraway (1983) Isolation of actincontaining transmembrane complexes from ascites adenocarcinoma sublines having mobile and immobile receptors. Proc. Natl. Acad. Sci. U. S. A. $80: 430-434$.

Condeelis, J. (1979) Isolation of concanavalin A caps during various stages of formation and their association with actin and myosin. J. Cell Biol. 80 751-758.

Connolly, J. L., L. A. Greene, R. R. Viscarello, and W. D. Riley (1979) Rapid, sequential changes in surface morphology of $\mathrm{PC} 12$ pheochromocytoma cells in response to nerve growth factor. J. Cell Biol. 82: 820-827.

DeBault, C. E. (1973) A critical point drying technique for SEM of tissue culture cells grown on plastic substratum. Illinois Institute of Technology Research Institute (IITRI)/SEM: 317-324.

Flanagan, J., and G. L. E. Koch (1978) Cross-linked surface lg attaches to actin. Nature 273: 278-281.

Greene, L. A., and A. S. Tischler (1976) Establishment of a noradrenergic clonal line of rat adrenal pheochromocytoma cells which respond to nerve growth factor. Proc. Natl. Acad. Sci. U. S. A. 73: 2424-2428.

Grob, P. M., and M. A. Bothwell (1983) Modification of nerve growth factor reccptor propertics by wheat germ agglutinin. J. Biol. Chem. 258: 14136 14143.

Gundersen, R. W., and J. N. Barrett (1979) Neuronal chemotaxis: Chick dorsal-rool axons turn loward thigh concentralions of nerve growlh factor. Science 206: 1079-1080.

Hellewell, S. B., and D. L. Taylor (1979) The contractile basis of ameboid movement. VI. The solation-contraction hypothesis. J. Cell Biol. 83: 633648.

Herrup, K., and H. Thoenen (1979) Properties of the nerve growth factor receptor of a clonal line of rat pheochromocytoma (PC12) cells. Exp. Cell Res. 121: 71-78.

Hosang, M., and E. M. Shooter (1985) Molecular characteristics of nerve growth factor receptors in PC12 cells. J. Biol. Chem. 260: 655-662.

Hubbard, A. L., and A. Ma (1983) Isolation of rat hepatocyte plasma membranes. II. Identification of membrane-associated cytoskeletal proteins. J. Cell Biol. 96: 230-239.

Hynes, R. O. (1973) Alteration of cell-surface proteins by viral transformation and by proteolysis. Proc. Natl. Acad. Sci. U. S. A. 70: 3170-3174.

Jesaitis, A. J., J. R. Naemura, L. A. Sklar, C. G. Cochrane, and R. G. Painter (1984) Rapid modulation of $\mathrm{N}$-formyl chemotactic peptide receptors on the surface of human granulocytes: Formation of slowly dissociating ligandreceptor complexes in transient association with cell cytoskeleton. J. Cell Biol. 98: 1378-1387.

Jung, G., R. M. Helm, C. A. C. Carraway, and K. L. Carraway (1984) Mechanism of concanavalin A-induced anchorage of the major cell surface glycoproteins to the submembrane cytoskeleton in 13762 ascites mammary adenocarcinoma cells. J. Cell Biol. 98: 179-187.

Koppel, D. E., M. P. Sheetz, and M. Schindler (1981) Matrix control of protein diffusion in biological membranes. Proc. Natl. Acad. Sci. U. S. A. 78: 3576-3580

Kopriwa, B. M., and L. P. Leblond (1962) Improvement in the coating technique of radioautography. J. Histochem. Cytochem. 10: 269-284.

Landreth, G. E., and E. M. Shooter (1980) Nerve growth factor receptors in PC12 cells: Ligand-induced conversion from low to high affinity states. Proc. Natl. Acad. Sci. U. S. A. 77: 4751-4755.

Levi, A., Y. Shechter, E. J. Neufeld, and J. Schlessinger (1980) Mobility, clustering and transport of nerve growth factor in embryonal sensory cells and in a sympathetic neuronal cell line. Proc. Natl. Acad. Sci. U. S. A. 77: 3469-3473.

Mescher, M. F., M. J. L. Jose, and S. P. Balk (1981) Actin-containing matrix associated with the plasma membrane of murine tumor and lymphoid cells. Nature 289: 139-144.

Mobley, W. C., A. Schenker, and E. M. Shooter (1976) Characterization and isolation of proteolytically modified nerve growth factor. Biochemistry 15: 5543-5551.

Nicholls, R., C. E. Chandler, and E. M. Shooter (1981) Enucleation of PC12 cells. Soc. Neurosci. Abstr. 7: 150.

Painter, R. G., and M. Ginsberg (1982) Concanavalin A induces interactions between surface glycoproteins and the platelet cytoskeleton. J. Cell Biol. 92: 565-573.

Pober, J. S., B. C. Guild, J. L. Strominger, and W. R. Veatch (1981) Purification of HLA-A2 antigen, fluorescent labeling of its intracellular region, and demonstration of an interaction between fluorescently labeled HLA-A2 antigen and lymphoblastoid cell cytoskeleton proteins in vitro. Biochemistry 20: $5625-5633$.

Prives, J., A. B. Fulton, S. Penman, M. P. Daniels, and C. N. Christian (1982) Interaction of the cytoskeletal framework with acetylcholine receptor on the surface of embryonic muscle cells in culture. J. Cell Biol. 92: 231-236.

Puma, P., S. E. Buxser, L. Watson, D. J. Kelleher, and G. L. Johnson (1983) Purification of the receptor for nerve growth factor from A875 melanoma cells by affinity chromatography. J. Biol. Chem. 258: 3370-3375.

Sahyoan, N. E., H. Le Vine III, J. Davis, G. M. Hebdon, and P. Cuatrecasas (1981) Molecular complexes involved in the regulation of adenylate cyclase. Proc. Natl. Acad. Sci. U. S. A. 78: 6158-6162.

Salisbury, J. L., J. S. Condeelis, and P. Satir (1980) Role of coated vesicles, microfilaments, and calmodulin in receptor-mediated endocytosis by cultured B lymphoblastoid cells. J. Cell Biol. 87: 132-141.

Schechter, A. L., and M. A. Bothwell (1981) Nerve growth factor receptors on PC12 cells: Evidence for two receptor classes with differing cytoskeletal association. Cell 24: 867-874.

Schlessinger, J., D. Axelrod, D. E. Koppel, W. W. Webb, and E. L. Elson (1976) Lateral transport of a lipid probe and labeled proteins on a cell membrane. Science 195: 307-309.

Schlessinger, J., E. L. Elson, W. W. Webb, I. Yahara, U. Rutishauser, and G. M. Edelman (1977) Receptor diffusion of cell surfaces modulated by locally bound concanavalin A. Proc. Natl. Acad. Sci. U. S. A. 74: 1110-1114.

Seeley, P. J., arid L. A. Greene (1983) Storttatency local aclions of nerve growth factor at the growth cone. Proc. Natl. Acad. Sci. U. S. A. 80: 27892793.

Sheterline, P., and C. R. Hopkins (1981) Transmembrane linkage between surface glycoproteins and components of the cytoplasm in neutrophils. J. Cell Biol. 90: 743-754.

Stossel, T. P. (1982) The structure of cortical cytoplasm. Philos. Trans. R. Soc. lond. (Biol.) 299: 275-289.

Sutter, A., R. J. Riopelle, R. M. Harris-Warrick, and E. M. Shooter (1979a) Nerve growth factor receptors. Characterization of two distinct classes of binding sites on chick embryo sensory ganglia cells. J. Biol. Chem. 254: 5972-5982.

Sutter, A., R. J. Riopelle, R. M. Harris-Warrick, and E. M. Shooter (1979b) The heterogeneity of nerve growth factor receptors. In Transmembrane Signaling, M. Bitensky, R. J. Collier, D. F. Steiner, and C. F. Fox, eds., pp. 659-667, Alan Liss Inc., New York.

Thoenen, H., and Y. A. Barde (1980) Physiology of nerve growth factor. Physiol. Rev. 60: 1284-1334.

Vale, R. D., and E. M. Shooter (1982) Alteration of binding properties and cytoskeletal attachment of nerve growth factor receptors in $\mathrm{PC} 12$ cells by wheat germ agglutinin. J. Cell Biol. 94: 710-717.

Vale, R. D., and E. M. Shooter (1983) Conversion of nerve growth factorreceptor complexes to a slowly dissociating. Triton X-100 insoluble state by anti nerve growth factor antibodies. Biochemistry 22: 5022-5028.

Woda, B. A., and M. L. McFadden (1983) Association of lymphocyte membrane proteins with the detergent-insoluble cytoskeletal matrix. Fed. Proc. 42: 321.

Yankner, B. A., and E. M. Shooter (1979) Nerve growth factor in the nucleus: Interaction with receptors on the nuclear membrane. Proc. Natl. Acad. Sci. U. S. A. 76: 1269-1273

Yankner, B. A., and E. M. Shooter (1982) The biology and mechanism of action of nerve growth factor. Annu. Rev. Biochem. 51: 845-868. 